\title{
Badger's Cold Storage Plant
}

by JOYCE DEW, Saskatchewan Museum of Natural History

The Badger (Taxidea taxus), the largest member of the mustelid family on the Saskatchewan plains, is a rodent destroyer of some consequence. Cahalane in "Mammals of North America" gives the following information on his diet: "Rodents make up by far the largest item; but ground squirrels, field mice, and deer mice, rabbits, insects and groundnesting birds and their eggs are included in the northern and eastern parts of the United States. In the southwest, the badger eats ground squirrels, prairie dogs, pocket gophers, kangaroo rats, wood rats, mice, insects and lizards. It picks up birds' eggs as it chances upon them, not by systematic search."

With these preliminaries I feel reasonably safe in telling the following incident about a badger: Let not the scale of prejudices be weighted against his species for this episode. Cahalane mentions an incident whereby a Badger put some dead skunks in cold storage but as far as I know there is no previous published report of a Badger storing chickens. This happened on my father's farm at Riverhurst several years ago. Chickens were missing from the hen house. Sometimes several in one night would disappear; at other times several nights would pass with no depredations being made. Investigation showed that a
Badger was entering the hen house through a tunnel which he had excavated, beginning a few feet from the outer wall and going down underneath the foundation and up into the building. Attempts to capture the illusive beast proved futile. After some 40 fowls had disappeared the survivors were moved to other quarters. Test holes were dug in an attempt to find a tunnel apart from the one which the Badger used to enter the building. One such test disclosed a dead chicken, well preserved in the slightly damp, cold sand. Further digging revealed more chickens, each packed in sand and separated from the others in the tunnel. After unearthing five or six birds we abandoned the search. Undoubtedly furthur digging would have revealed more of the missing fowls. Whether or not the badger was storing the birds for winter use is a matter of speculation. None of the birds unearthed was mutilated and the fall season was well enough advanced to make cold storage feasible. Since beginning the preparation of this article, I have heard another report of a Badger engaged in a similar activity. Fred Lahrman states that on his father's farm at Mortlach, a dozen or more fowls were found packed in sand where they had been hidden by an errant Badger.

\section{Extension of the Range of the Short-tailed Shrew}

\section{by ROBERT W. NERO, Sakatchewan Museum of Natural History}

Members of the 4-H Club participating in the leadership training course at Wakaw Lake, 35 miles south of Prince Albert, received a very special reward for their efforts in operating a small mammal trapline. On August 19, 1957, they caught a Short-tailed Shrew (Blarina brevicauda), thereby extending the known range of Blarina some 75 miles northwest to within 20 miles of the South Saskatchewan River. Judging by this new record this species occupies a range in Saskatchewan covering at least all of the parkland belt from the Manitaba border to the Saskatchewan River (see Blue Jay, $14: 45,15: 121)$. It is questionable whether they occur north of the river since J. Dewey Soper did not find any in Prince Albert National Park (1951. The mammals of P.A.N.P., Sask., Can. Wildlife Mgt. Bull., Series 1, No. 5. Ottawa). However, only further collecting will provide the final answer.

The trap-line activity of the 4-H leaders at Camp Wakaw was directed by Richard W. Fyfe, Museum Extension Officer, and was part of a 